\title{
Ethnic differences in accident rates at work
}

\author{
C C BAKER* \\ From the Ford Motor Company, Dagenham, Essex, UK
}

ABSTRACT The accidents at work of 4482 employees in a car engine machining and assembly plant $\stackrel{\circ}{-}$ in south east England were studied retrospectively over a 12 month period. The study population $\vec{\omega}$ was composed of Asian (22\%), white (66\%), and West Indian employees (12\%). The crude accident $\stackrel{\circ}{\circ}$ rates differed among the groups, the means being Asians $1 \cdot 58$, white $1 \cdot 23$, and West Indians $1 \cdot 28$. $\frac{\Phi}{3}$ There was, however, no consistent ethnic difference after adjustment for other factors such as age, type of job, and duration of service. Accident rates were higher in those employees who were $\dot{\omega}$ younger, newly employed, and in production jobs. The findings of this research imply that accident $\tilde{O}_{0}$ prevention programmes should be directed to those factors known to relate to accidents and not to any specific ethnic group.

Prevalence of a wide variety of diseases varies in different ethnic groups. ${ }^{1}$ The certified sickness absence pattern in the same population as the present study was found earlier to differ among the groups. ${ }^{2}$ From the findings of these papers it could be supposed that the accident rate at work would also vary. Suchman found that a cultural factor was important in accident causation. ${ }^{3}$ Several studies conducted in Europe have shown that the immigrant suffers more accidents $^{4-8}$ (E Aujaleu, $P$ Andlauer, paper presented to ILO/WHO Committee on Occupational Health, Geneva, 1975), and a WHO report stated that accidents were both more common and more severe among foreign workers. ${ }^{7}$ The accident rate varied according to the type of employment and the country of origin of the worker. Two studies in Europe found that the immigrant had more accidents in the first year but then his accident rate became the same as that of a resident of the country. ${ }^{910}$ Studies in the United States ${ }^{11}$ and Singapore ${ }^{12}$ also show a higher incidence of accidents among immigrants.

The fewer studies in the United Kingdom is probably because the scientific study of ethnic differences has often been influenced by politics and philosophy, stifling objective investigation and rational discussion. ${ }^{13}$ Recorded information on ethnicity of employees is rarely held by an employer; I was aware of only one other large company keeping such records. Wright reported interviews with managers

*Present address: Public Health Service, SA Health Commission, Box 1313 GPO, Adelaide 5001, South Australia.

Accepted 28 May 1986 from several companies who stated that Asians had a higher incidence of accidents, but his report was anecdotal. ${ }^{14}$ The Department of Employment conducted a study of seven companies. ${ }^{15}$ Only one company maintained a numerical record of accidents and there was evidence of a higher incidence of notifiable industrial accidents among coloured immigrants. In another company a trade union district official stated that coloured immigrants seemed to make more accident claims; managers of three other companies stated that coloured workers were no more prone to accidents than white workers. Castle and Kosack reported high numbers of accidents for migrant workers, and this included Asians in Britain. ${ }^{16}$ The findings in Britain, however, were based on Wright's anecdotal evidence. Another study found that coloured immigrant workers had more accidents. ${ }^{17}$ Khogali briefly reported his study on occupational accidents in a large factory where one third of the workforce were foreign workers and there was a statistically significant difference $(p<0.001)$ between $\frac{D}{O}$ the two groups with the foreign workers having the higher accident rate. ${ }^{18}$ Lee and Wrench found that in $N$ three out of four factories employing Asians the crude accident rate was highest in this ethnic group. ${ }^{19}$ The 0 difference was found to disappear, however, when the $\omega$ groups were compared according to the types of job on which they were engaged.

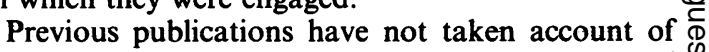
confounding factors such as age and duration of $\stackrel{\oplus}{+}$ service or have not compared accident rates in 0 employees doing similar jobs. This study has been designed to take account of such limitations. 
Method

A retrospective survey of accidents was conducted at one plant of a large vehicle manufacturing company in south east England at which a range of engines was machined and assembled. The study was designed to test the null hypothesis that there was no significant difference in accident rates between the three ethnic groups, white, Asian, and West Indian.

Study population-The study population was the cohort of male employees identified in the previous study, ${ }^{2}$ all of whom were employed for the full year of the study. For each employee, age, duration of service, job grade, department, and ethnic group were recorded. Workers were grouped by payment in relation to the skills required for the job.

$J o b$ grades-The classification of job grades used the company's system of grading. Grade 1 consisted of unskilled production workers, storemen, and machine operators. Grade 2 were mostly production workers who required more skill, repairmen, and grinders. Grades 3 and 4 were mainly non-production staff consisting of millwrights, welders, and drivers in grade 3 and the most skilled, electricians, toolmakers, and turners, in grade 4.

Accidents-The medical department's records were used to identify the number of accidents each employee suffered during 1979. Only accidents occurring at work were recorded in the study. An accident was recorded when an employee reported to the medical department, stating that he had received an injury at work. Company regulations require an employee to report every accident and most of these were trivial (minor cuts and abrasions or attendance with no evidence of injury).

\section{Results}

A total of 4482 employees were included in the study; 2954 (66\%) white, 972 (22\%) Asian, and $556(12 \%)$ West Indian.

Table 1 shows the distribution of accidents by age. In the youngest age group the mean number of accidents was $2 \cdot 09$. With increasing age, the mean number of accidents reduced, so that in the oldest age group it was 0.96 .

Table 2 shows the distribution of accidents by duration of service. Employees with the longest service had the fewest accidents ( 0.96 accidents per man). The accident mean increased so that in the shortest serving employees it was 1.78 accidents per man.

Table 3 shows the distribution of accidents by job grade of the employees. The lowest graded employees had the highest accident rate $(1.41$ accidents per man). The mean number of accidents was less for job
Table 1 Distribution of accidents by age on I January 1979

\begin{tabular}{llll}
\hline Age (years) & No of men & $\begin{array}{l}\text { Mean accidents } \\
\text { per man }\end{array}$ & $S D$ \\
\hline $15-24$ & 367 & $2 \cdot 09$ & $2 \cdot 70$ \\
$25-34$ & 879 & 1.50 & $2 \cdot 20$ \\
$35-44$ & 965 & 1.40 & $2 \cdot 22$ \\
$45-54$ & 1161 & $1 \cdot 18$ & 1.86 \\
$55-64$ & 1110 & 0.96 & 1.84 \\
All ages & 4482 & 1.31 & $2 \cdot 11$ \\
\hline
\end{tabular}

Table 2 Distribution of accidents by duration of service

\begin{tabular}{llll}
\hline $\begin{array}{l}\text { Duration of } \\
\text { service (years) }\end{array}$ & No of men & $\begin{array}{l}\text { Mean accidents } \\
\text { per man }\end{array}$ & $S D$ \\
\hline $1-5$ & 1208 & 1.78 & 2.54 \\
$6-10$ & 1229 & 1.33 & 1.92 \\
$11-20$ & 715 & 1.14 & 1.94 \\
$\geqslant 21$ & 1330 & 0.96 & 1.83 \\
\hline
\end{tabular}

Table 3 Accident distribution by job grade

\begin{tabular}{|c|c|c|c|}
\hline Job grade & No of men & $\begin{array}{l}\text { Mean accidents } \\
\text { per man }\end{array}$ & $S D$ \\
\hline \multirow{4}{*}{$\begin{array}{l}1 \\
\text { (cleaner, storeman, } \\
\text { machine operator) } \\
2 \\
\text { (repairman, grinder) } \\
3 \\
\text { (millwright, welder, } \\
\text { HGV driver) } \\
4 \\
\text { (electrician, } \\
\text { toolmaker, turner) }\end{array}$} & 1527 & 1.41 & $2 \cdot 23$ \\
\hline & 1854 & 1.24 & 2.01 \\
\hline & 312 & $1 \cdot 24$ & 1.79 \\
\hline & 789 & $1 \cdot 32$ & $2 \cdot 20$ \\
\hline
\end{tabular}

Table 4 Accident distribution by department

\begin{tabular}{llll}
\hline Department & No of men & $\begin{array}{l}\text { Mean accidents } \\
\text { per man }\end{array}$ & $S D$ \\
\hline $\begin{array}{l}\text { Non-production } \\
\text { Production }\end{array}$ & 1977 & $1 \cdot 18$ & $2 \cdot 06$ \\
\hline
\end{tabular}

grades 2 and 3 but then the mean increased for the most skilled employees ( 1.32 accidents per man). The range, however, was much smaller than those found for both age and duration of service. Employees in the production department had more accidents (mean $1.42)$ than the employees in non-production departments (mean 1.18) (table 4).

Asian employees, on average, had more accidents (mean 1.58) than the white (mean 1.23) and the West Indian (mean 1.28) employees (table 5). A smaller percentage $(39.4 \%)$ of Asians had no accidents compared with $49.4 \%$ of white and $45.1 \%$ of West Indians. The number of employees and the mean number of accidents for three ethnic groups by 20 subgroups 
of the sample, stratified simultaneously by type of department, job grade - that is, skill level - and year of first employment is given in table 6 . There is no obvious association between ethnic group and accident risk. Each of the three ethnic groups shows relatively low, middle, and high accident means, depending on the stratum. A similar stratum specific analysis using age instead of year of employment also failed to provide evidence for a consistent effect of ethnicity. With such results it was not considered good practice to apply summary measures (adjusted rates, for example) in order to compare the ethnic groups. Such summary measures would serve only to mask the underlying variability of the data.

A second analysis was conducted to detect whether there existed any significant effect of ethnicity on acci- $\overline{\mathrm{D}}$ dent risk. Each employee was given a code indicating whether or not he had had at least one accident on record. The statistical package BMDP was used to develop two logistic regression models. Both models aimed to predict the odds that a given employee hade had at least one accident. The predictions were made on the basis of the variables: department (two strata) $\varrho$ ethnicity (three strata), and grade (four strata, treatedes as an interval variable, 1-4). One model also included $\overrightarrow{0}$ year of employment whereas the other modelincluded year of birth, both treated as interval vari- $\vec{\omega}$ ables. In both models ethnicity was not associatedo with accident risk to a statistically significant degree ${ }_{3}^{\mathbb{D}}$ (table 7).

Table 5 Distribution of accidents in three ethnic groups

\begin{tabular}{|c|c|c|c|c|}
\hline No of accidents & White & Asian & West Indian & All groups \\
\hline $\begin{array}{l}0 \\
1 \\
2 \\
3 \\
4 \\
5-9 \\
\geqslant 10\end{array}$ & $\begin{array}{r}1458 \\
701 \\
337 \\
177 \\
111 \\
140 \\
30\end{array}$ & $\begin{array}{r}383 \\
227 \\
144 \\
85 \\
55 \\
68 \\
9\end{array}$ & $\begin{array}{r}251 \\
156 \\
61 \\
34 \\
21 \\
33 \\
7\end{array}$ & $\begin{array}{r}2092 \\
1084 \\
542 \\
296 \\
187 \\
234 \\
46\end{array}$ \\
\hline $\begin{array}{l}\text { Total } \\
\text { Mean } \\
\text { SD }\end{array}$ & $\begin{array}{r}2954 \\
1 \cdot 23 \\
2 \cdot 10\end{array}$ & $\begin{array}{r}972 \\
1 \cdot 58 \\
2 \cdot 16\end{array}$ & $\begin{array}{r}556 \\
1 \cdot 28 \\
2.03\end{array}$ & $\begin{array}{c}4482 \\
1 \cdot 31 \\
2 \cdot 11\end{array}$ \\
\hline
\end{tabular}

Table 6 Number of employees, and mean number of accidents, for three ethnic groups, by department (D)/grade (G)/year of employment (Y) stratum. Strata with fewer than 11 employees are excluded*

\begin{tabular}{|c|c|c|c|c|c|c|}
\hline \multirow{3}{*}{$\begin{array}{l}\text { Stratum } \\
D G Y\end{array}$} & \multicolumn{6}{|c|}{ Ethnic group } \\
\hline & \multicolumn{2}{|c|}{ White } & \multicolumn{2}{|c|}{ Asian } & \multicolumn{2}{|c|}{ West Indian } \\
\hline & No & Mean & $N o$ & Mean & $N o$ & Mean \\
\hline $\begin{array}{lll}1 & 1 & 2 \\
1 & 1 & 3 \\
1 & 1 & 4 \\
1 & 2 & 2 \\
1 & 2 & 3 \\
1 & 2 & 4 \\
1 & 3 & 3 \\
1 & 3 & 4 \\
1 & 4 & 2 \\
1 & 4 & 3 \\
1 & 4 & 4 \\
2 & 1 & 2 \\
2 & 1 & 3 \\
2 & 1 & 4 \\
2 & 2 & 2 \\
2 & 2 & 3 \\
2 & 2 & 4 \\
2 & 3 & 2 \\
2 & 3 & 3 \\
2 & 3 & 4\end{array}$ & $\begin{array}{r}97 \\
108 \\
216 \\
51 \\
127 \\
267 \\
43 \\
69 \\
134 \\
202 \\
423 \\
33 \\
51 \\
227 \\
151 \\
255 \\
394 \\
26 \\
35 \\
34\end{array}$ & $\begin{array}{l}1.34 \\
0.73 \\
1.04 \\
1.02 \\
1.10 \\
1.02 \\
1.16 \\
1.16 \\
1.40 \\
1.40 \\
1.30 \\
0.73 \\
0.80 \\
2.00 \\
1.29 \\
0.99 \\
1.19 \\
1.27 \\
0.89 \\
1.97\end{array}$ & $\begin{array}{r}42 \\
6 \\
34 \\
25 \\
2 \\
16 \\
0 \\
1 \\
3 \\
6 \\
12 \\
102 \\
3 \\
343 \\
170 \\
10 \\
142 \\
35 \\
6 \\
12\end{array}$ & $\begin{array}{l}1.10 \\
0.83 \\
1.18 \\
1.00 \\
1.00 \\
1.56 \\
\\
3.00 \\
1.67 \\
0.83 \\
0.58 \\
1.07 \\
0.00 \\
1.89 \\
1.52 \\
1.40 \\
1.80 \\
1.34 \\
1.17 \\
1.92\end{array}$ & $\begin{array}{r}30 \\
9 \\
13 \\
10 \\
8 \\
4 \\
1 \\
0 \\
2 \\
1 \\
4 \\
94 \\
19 \\
100 \\
138 \\
36 \\
47 \\
25 \\
13 \\
2\end{array}$ & $\begin{array}{l}1.50 \\
0.56 \\
0.92 \\
2.40 \\
0.13 \\
0.50 \\
1.00 \\
0.50 \\
0.00 \\
0.75 \\
1.47 \\
0.47 \\
1.37 \\
1.30 \\
1.31 \\
1.53 \\
1.00 \\
0.08 \\
3.00\end{array}$ \\
\hline
\end{tabular}


Table 7 Results of logistic regression analysis using two models

\begin{tabular}{|c|c|c|c|}
\hline Variable & Coefficient & Standard error & Statistically significant§ \\
\hline $\begin{array}{l}\text { Model I } \\
\text { Ethnic } 1^{*} \\
\text { Ethnic } 2 \dagger \\
\text { Department }+ \\
\text { Year of employment } \S \\
\text { Grade }\end{array}$ & $\begin{array}{r}-0.104 \\
0.072 \\
0.092 \\
0.030 \\
0.083\end{array}$ & $\begin{array}{l}0.064 \\
0.056 \\
0.036 \\
0.003 \\
0.033\end{array}$ & $\begin{array}{l}\text { No } \\
\text { No } \\
\text { Yes } \\
\text { Yes } \\
\text { Yes }\end{array}$ \\
\hline $\begin{array}{l}\text { Model } 2 \\
\text { Ethnic } 1^{*} \\
\text { Ethnic } 2 \dagger \\
\text { Department }{ }_{\ddagger}^{\ddagger} \\
\text { Year of birth } \\
\text { Grade }\end{array}$ & $\begin{array}{r}-0.034 \\
0.080 \\
0.094 \\
0.021 \\
0.041\end{array}$ & $\begin{array}{l}0.063 \\
0.057 \\
0.036 \\
0.003 \\
0.032\end{array}$ & $\begin{array}{l}\text { No } \\
\text { No } \\
\text { Yes } \\
\text { Yes } \\
\text { No }\end{array}$ \\
\hline
\end{tabular}

* Ethnic 1 is a design variable that compares the white and West Indian groups.

†thnic 2 is a design variable that compares the white and Asian groups.

tDepartment is a design variable that compares the production and non-production departments.

\$The statistical significance of each variable's contribution to the regression model is determined by the variable's coefficient divided by its standard error. The resulting values may be read roughly as $t$ statistics. Useful variables in the model have $t$ values of at least $2 \cdot 0$.

\section{Discussion}

The findings support the conclusion that ethnicity in the present study group does not play a causative part in the occurrence of occupational accidents. The conclusion is justified, though, only to the extent that one is confident that factors other than ethnicity which influence accident occurrence have been adequately controlled. The most important, and most trivial, of these factors is the nature of work done, or tasks required. Clearly some tasks are inherently more dangerous than others. If relatively dangerous tasks tended to fall to members of a particular ethnic group the group might well have raised accident rates and these rates could be incorrectly attributed to ethnicity per se.

It was not possible in the present study of the effects of ethnicity on accident occurrence to assess the hazard of each worker's job. Instead, two proxy measures of hazard were used, department and grade. One expects production departments to be more hazardous than non-production departments and that grade is associated with task and therefore with hazard. Whereas duration of employment might relate to task as well (seniority usually has its privileges), this variable probably acts on accident occurrence through the direct effect of experience. In any event, when department and grade were controlled, ethnicity did not appear to have an independent effect on accident risk.

PERSONAL FACTORS OTHER THAN ETHNICITY Hale and Hale in their review of publications on accidents found that during the teens and early 20 s the number of accidents was high. ${ }^{20}$ The accident rate then dropped sharply as age increased and levelled out in the mid-20s. In the present study the accident rate declined sharply from 2.09 accidents per man in the youngest age group to 1.50 accidents per man in the 25-34 year age group. Several studies have suggested that younger workers have more accidents for reasons other than inexperience. Suggested reasons include inattention, indiscipline, impulsiveness, misjudgment, overestimation of capacity and pride, recklessness, and lack of family responsibilities. ${ }^{21}$ Possibly all these suggestions are correct but they are mainly the authors' subjective impressions. Hale and Hale state that as the employee ages accidents decline slightly until the middle or late 40 s when the numbers start to rise again, ${ }^{20}$ but table 1 shows, in the present study, that as the employee ages the accident rate is reduced. There is no increase in incidence in the oldest age group (55-64). Other studies have found that the older worker had more accidents because of poor motor coordination, lack of mental agility, sensory deficiencies, and the longer time required by the older worker to learn when put into a new situation. The oldest age group in our study population was composed of a high proportion of job grade 3 and 4 employees and therefore that group was at lower risk from accidents.

Studies have shown that accident rates drop sharply after about the first two years of service. 202223 Wohlberdt found that the accident rate started to increase again after the employee had completed three years of service ${ }^{22}$; other researchers, however, found that age is the most important factor after the first few years. ${ }^{2023}$ That finding, however, differs from the present study where duration of service was a more important factor than age. In this study all the employees had completed at least one year with the company and as the duration of service increased, the accident rate decreased. This is consistent with another paper in which 2367 accidents at 
work in four different types of industrial workshop were examined. ${ }^{24}$ At three of the workshops there was a decreased accident frequency as the duration of service increased. In the fourth workshop so few people had short service that the relation could not be studied.

Employees undertaking the unskilled and more arduous jobs have higher accident rates than the skilled workers. Table 4 shows that the production employees on the assembly line have more accidents than the repairmen, drivers, and storemen in the nonproduction departments. In the analysis of accidents by job grade in our study (table 3 ), however, there is no clear relation, possibly because of the variety of jobs in each grade. The lowest grade employees have the highest rate: the rate is reduced and the same for job grades 2 and 3 and increases in the most skilled workers. Perhaps the highly skilled workers are more conscientious in reporting accidents or are at greatest risk.

\section{ETHNIC GROUP}

Previous work has shown that the immigrant has a greater number of accidents than a person born in the host country. In the studies that have attempted to identify the cause through the individual's job the finding was that the immigrants were rarely encountered in any of the skilled craft areas of work but were most widely represented in heavy, dirty jobs. ${ }^{19}$ In these jobs the immigrant is more at risk due to the machinery and the heavy work undertaken. ${ }^{25}$ In any study it is important to compare employees who are undertaking the same type of job and are therefore exposed to similar risks. ${ }^{26}$ Age and duration of service are two of the most common confounding factors in an investigation of this type. In a study where different groups of employees are compared it is essential that some form of standardisation is undertaken ${ }^{26} 27$ but most authors have not taken these factors into account. A few have standardised for age, but only one study ensured that some type of standardisation for job was undertaken and in that study there was no age standardisation. ${ }^{19}$ In the analyses undertaken in the present study stratification and regression analysis have been undertaken to allow comparison between the different groups.

\section{INFERENCE DRAWN FROM THE STUDY}

The findings of the present study support those of Lee and Wrench, who concluded from analysing the result of 4110 accidents from five study populations that there was no evidence to indicate that cultural background is related to industrial accident rates. ${ }^{19}$ The findings of this research imply that it is not necessary, at least in the present study group, to design special accident prevention programmes for specific ethnic groups. In other groups of ethnic workers, where perhaps facility in English may not be a ? requirement for employment as in the factory studied $\overrightarrow{\overrightarrow{\vec{S}}}$ in this paper, specially tailored preventive programmes may well be advisable.

I acknowledge the help of Dr R Somers, South Australian Health Commission, for his help in analysis and interpretation of the data.

\section{References}

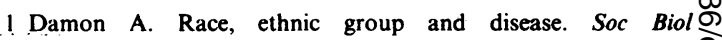
1969;16:69-80.

2 Baker CC, Pocock SJ. Ethnic differences in certified sickness absence. Br J Ind Med 1982;39:277-82.

3 Suchman EA. Cultural and social factors in accident occurrence $\vec{A}$ and control. J Occup Med 1965;7:487-92.

4 Godard J. Problemes de sécurité posés par les travailleurs î migrants. Santé de l'homme 1972:117 supplement.

5 Fisek NH. Study on the health aspects of labour migration in $\mathrm{O}$ Europe with special reference to epidemiological studies. Copenhagen: World Health Organisation Regional Office for $\vec{Z}$ Europe, 1973. (Working paper EURO 4003/8.)

6 World Health Organisation. Health aspects of labour migration. (Report on a working group convened by the Regional Office $\frac{\rho}{\supset}$ for Europe of the World Health Organisation, Algiers 1973.) Copenhagen: WHO, 1974. (EURO 4003.)

7 Mynick R, Kleback S. Fremmedarbejderes kontaktmonster med $\stackrel{\infty}{\sim}$ den primaere laegetjeneste i Kobenhavns kommune. Ugeskr Laeg 1976;138:2976-80.

8 Wandrey E. Arbeitsunfallanalyse eines Grossbetriebes. Arbeitsmedizin Sozialmedizin Präventivmedizin 1976; 11:186-92.

9 Bresson JR, Neulat G, Palasse J. La pathologie des migrants en

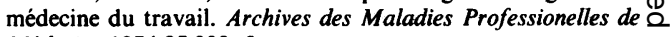
Médecine 1974;35:992-5.

10 Girard R. Etude de l'absentéisme des travailleurs étrangers (à propos d'une enquête effectuée chez 775 immigrants). Archives de Maladies Professionelles de Médecine 1968;29:730-2.

11 Fuentes JA. The need for effective and comprehensive planning? for migrant workers. Am J Public Health 1974;64:2-10.

12 Bong A, Chao TC, Lee J. Risks of death from industrial accidents $\mathbb{\Phi}$ of foreign workers in Singapore. Ann Acad Med Singapore 3 1976;5:138-42.

13 Anonymous. Ethnic factors and disease. $\mathrm{Br}$ Med $\mathrm{J}$ 1981;282:1496-7.

14 Wright PL. The coloured worker in British industry. London: Oxford University Press, 1968.

15 Department of Employment. Take 7. (Report on a survey under-응 taken by the Department of Employment into immigrant labour relations at seven English firms.) London: HMSO, $\frac{D}{2}$ 1972.

16 Castle S, Kosack G. Immigrant workers and the class structure in Western Europe. London: Oxford University Press, 1973.

17 Afonja SA. Daily variations of industrial accidents: an index of $\mathrm{N}$ work alienation. Journal of Occupational Accidents 1979;2: 209-26.

$18 \mathrm{Khogali} \mathrm{M}$. The role of the occupational medical service in the United Kingdom in promoting health of migrant workers. In: Safety and health of migrant workers-internationalo symposium, Gavtat Dubrovnick 1977. ILO Occupational Safety \& Health Series 1979;41:171-7.

19 Lee G, Wrench J. Accident-prone immigrants: an assumption 7 challenged. Sociology 1980;14:551-66.

20 Hale AR, Hale M. A review of the industrial accident research literature by the National Institute of Industrial Psychology. 
London: HMSO, 1982. (Research paper for the Committee on Safety and Health at Work).

21 International Occupational Safety and Health Information Centre (CIS). Human factors and safety. (CIS information sheet No 15.) Geneva: International Labour Office, 1967.

22 Wohlberdt F. During what period of employment do most occupational accidents occur? Der Kompass Bochum 1957;77:37-41.

23 Boyle AJ. Statistical and simulation studies of accident susceptihility in industrial tasks. London: University of London, 1980. (PhD thesis.)

24 Powell P, Hale M, Martin J, Simon M. 2000 accidents. A shop floor study of their causes based on 42 months' continuous observation. London: National Institute of Industrial Psychology, 1971.

25 Kopplemann J. Die erhöhte Unfallgefährdung einiger Bevölkerungsgruppen unter besonderer Berücksichtigung der Handverletzungen. Monatsschrifi Unfallheilkunde 1974;77: 266-76.

26 Desoille H, Scherrer J. Truhaut R. Travailleurs migrants et maind'oeuvre étrangère. In: Précis de médecine de travail. 3rd ed. Paris: Masson, 1980:946-51.

27 Schmoll HJ. Zum Krankenstand der ausländischen Arbeitnehmer. $M M W$ 1973;115:2280-4.

\section{Destruction of manuscripts}

From 1 July 1985 articles submitted for publication will not be returned. Authors whose papers are rejected will be advised of the decision and the manuscripts will be kept under security for three months to deal with any inquiries and then destroyed. 